Hartono Yudo

Serliana Yulianti

Ovin Ranica Pratiwi

Tuswan Tuswan

http://dx.doi.org/10.21278/brod72303

\title{
THE CONVERSION STRATEGY FROM LANDING CRAFT TANK INTO LIVESTOCK CARRIER: AN OVERVIEW OF TECHNICAL EVALUATION AND ECONOMICAL BENEFIT
}

UDC 629.5.083.6:629.5.015.1: 629.5.015.2:629.5.017.2

Original scientific paper

\begin{abstract}
Summary
The conversion of Landing Craft Tank into Livestock Carrier as an alternative solution was conducted by performing technical and economic assessments. The conversion analysis of LCT vessels to Livestock Carrier was achieved by performing layout rearrangement, stability test, seakeeping, and resistance test to measure the technical change occurring due to the modification. The economic added-value analysis was conducted by calculating the payback period to determine the estimated time needed to recover the cost of an investment. The result showed that the conversion of LCT ships has a good technical assessment. The intact and damage stability performance qualifies the standard criteria given by the IMO standard. The motion result qualifies the standard according to the type of vessel in terms of heave, pitch, and roll motions. Moreover, the resistance of the Livestock Carrier is reduced due to a decrease in displacement and draft. In terms of economic assessment, the Livestock Carrier conversion project qualifies for investment projects and improves the use-value and economy of a business segment.
\end{abstract}

Key words: $\quad$ ship conversion; Landing Craft Tank; Livestock Carrier; seakeeping; resistance; stability; investment analysis.

\section{Introduction}

The Landing Craft Tank (LCT) ship was designed to carry combat and heavy equipment during World War II. LCT is a type of ship used by the British and United States Navy to land tanks onshore [1]. To comprehend the safety aspect based on the decision of the Directorate General of Sea Transportation of Indonesia, LCT ships are forbidden to be used as ferry transportation. LCT is prohibited from being used in shipping activities. To anticipate losses due to the operational prohibition of LCT, a function modification is needed.

One alternative to solve the problem is the conversion of LCT vessels into Livestock Carrier. Due to the lengthy sailing period required to carry cattles between islands, the vessel should be designed specifically in order to provide dependable services for animal welfare even 
Hartono Yudo, Serliana Yulianti, The Conversion Strategy From Landing Craft Tank Into Livestock Carrier:

under adverse conditions during sea transportation [2]. Based on data obtained from the Animal Husbandry Statistic book in 2017, the livestock population increases every year. According to the Directorate General of the Ministry of Cross and Sea Transportation, transportation using Livestock Carrier pays more attention to animal welfare. This is evidenced by the decrease of livestock depreciation by $8-10 \%$ compared to transportation using cargo ships, which caused depreciation above $13 \%$. Therefore, to reduce damnification of ship owners due to the prohibition of using LCT as a mode of sea transportation and the increasing population of livestock, the conversion of LCT ships to livestock vessels for the transportation facility of live animals (sheep, cattle, pigs, goats, etc.) is an alternative solution [3].

Several technical and economic aspects need to be considered for conversion purposes to perform in operation with maximum profit. The shape of the hull underwater will affect the fluid flow characteristics around the ship, representing ship resistance. Ships consume a considerable amount of fuel to provide necessary propellant force to overcome resistance in their movement. Several studies have been conducted to reduce the resistance and powering on the ship's hull during operation by modifying the hull form [4-6]. The assessment of ship conversion in order to obtain high-level stability performance is also one of a crucial aspect. The stability during operation must fulfill the requirement of IMO standards. In addition to resistance and stability aspects, another essential aspect is its ability to maintain its position in water. It is challenging to improve the intrinsic seakeeping performance of a ship once it has been designed. Rolling, pitching, and heaving motion responses will have an impact on comfort, safety, and maneuverability. Aside from technical aspects, it is also crucial to conduct an economic investigation to ensure the ship conversion has an economic added value. Moreover, structural aspect in service during ship conversion is a crucial aspect to investigate the behaviour of the ship's structure in terms of stress level and other safety criteria in all considered load cases. Jurišić \& Parunov [7] conducted a strength assessment during conversion from general cargo ships to cement carriers. The analysis of longitudinal and local strength, and FE analysis of primary supporting members were conducted in all considered load cases. It can be found that the structural responses have satisfied Croatian Register of Shipping rule requirements.

Although the number of studies has risen considerably, the comprehensive evaluation in the technical and economic aspects regarding the ship conversion from LCT tank to Livestock Carrier is limited, especially in Indonesia. In this case, the ship conversion is evaluated by conducting technical measurements, including redesigning the ship layout, measuring the ship's structural weight, and considering the ship's performances numerically, including resistance test, stability, and ship motion. Moreover, the economic aspect is measured by calculating the feasibility level of LCT vessels after being converted into livestock vessels in the case of shipping from Kumai Port to Tanjung Perak Port, Surabaya.

\section{Theoretical background and method}

The ship conversion scenario was conducted by analyzing the technical and economic aspects. In the technical aspect, the initial step was the complete realignment of the LCT layout by adding some compartments on the main deck to transport the animals. The next step was calculating the lightweight and deadweight tonnage as an input to perform further technical analysis. The performance analysis, including the measurement of ship resistance and powering, ship stability, and motion, was calculated numerically in the technical analysis. The financial approach method included calculating NPV, IRR, and PP. Results were evaluated in the economic added-value study. 


\subsection{Intact and damage stability calculation}

Ship operation required a high level of ship stability, so stability calculation was essential for providing safety guidelines $[8,9]$. The fundamental concept of the state of stability is based on the equilibrium condiction depending on the relation between the center of gravity and the center of buoyancy. In this study, a stability test was performed numerically using Maxsurf Stability software for both intact and damage stability analysis. For the intact stability analysis, the test procedure was initially performed by defining all rooms/ compartments by adding the type of room, permeability, specific gravity, fluid type and compartment dimension of both ship types. The second step was done by defining the load case by setting the unit mass of each component, longitudinal arm, and transversal vertical arm. In this case, there are three loading conditions based on the difference in the quantity of mass of each component. In load case I, the cargo (truck \& livestock) was assumed to be in full load condition. The consumable components such as fuel oil, freshwater, lubrication oil and provision were set in full load $(100 \%)$. The cargo was set in full load in load case II, however consumable components were set in partial condition (50\%). In load case III, the cargo was set in full load condition with $10 \%$ of consumable components, as seen in Table 3. The vessel was assumed to be in regular operation, and the hull was not breached in any compartment. The analysis was performed by comparing the stability value to the limit standard. IMO MSC.267 (85) [10] was used for intact stability analysis of LCT and Livestock Carrier, as shown in Table 1.

The concept of probabilistic damage stability measures the probability of sufficient stability after flooding, to prevent capsize due to loss of stability and heeling moment. The damage stability test was performed using Maxsurf Stability, where IMO criteria MSC.216 (82) [11] was used as stability criteria. In the damage stability test, inputs of probabilistic damage calculations were: loading conditions, subdivisions, openings, key points, zones set up and global settings related to formulas, and the outputs were attained index of each damage case. The simulation of the damage zone is depicted in Fig. 1. The blue color shows the assumed damage lengthwise and vertically, the second blue box shows the assumed leakage lengthwise and transversely. It measures vertical damage from the ship keel to the top. It is caused by the leak in the ship's compartment that has been limited by the watertight walls on the ship.

The ship conversion falls under SOLAS requirements for probabilistic damage stability calculation. The technique computes the individual probability for all potential damage cases encountered by the ship, multiplied by the survivability of each individual damage scenario. The capacity of a vessel to stay afloat after being rammed by an arbitrary ship is described as survivability. The obtained index, $A$, is the sum of the probability and survival for all possible damage scenarios. This achieved index reflects whether the vessel can withstand specific damages in a way that ensures the safety of the crew and passengers on board. The probabilistic damage stability requirements demand that the obtained index value be equal to or less than the value of the required subdivision index, $R$ [12]. An attained subdivision index $A$ is obtained by the summation of the partial indices, and each partial index is a summation of contributions from all damage cases using Eq. 1.

$$
A_{c}=\sum_{1}^{i=t} p_{i}, \mathrm{~s}_{i}, v_{i}
$$

where $A_{c}$ is attained index for particular loading condition, $i$ is damage zone under consideration, $t$ is the number of damages that has to be investigated, $p$ is the probability that only the compartment or the group of compartments under consideration may be flooded, $v$ is the probability that the damage will not exceed a given height above the waterline, $s$ is the probability of survival after flooding the compartment. 
Hartono Yudo, Serliana Yulianti, The Conversion Strategy From Landing Craft Tank Into Livestock Carrier:

Table 1 IMO Stability Criteria

\begin{tabular}{|c|l|c|c|}
\hline Code & \multicolumn{1}{|c|}{ Criteria } & IMO Criteria & Unit \\
\hline & Area 0 to 30 & 3.151 & m.deg \\
\cline { 2 - 4 } & Area 0 to 40 & 5.156 & m.deg \\
\cline { 2 - 4 } $267(85)$ & Area 30 to 40 & 1.718 & m.deg \\
\cline { 2 - 4 } Ch2 & GZ & 0.200 & $\mathrm{~m}$ \\
\cline { 2 - 4 } & Angle of GZ 30 or greater & 25 & $\mathrm{deg}$ \\
\cline { 2 - 4 } & Initial GMt & 0.150 & $\mathrm{~m}$ \\
\hline
\end{tabular}
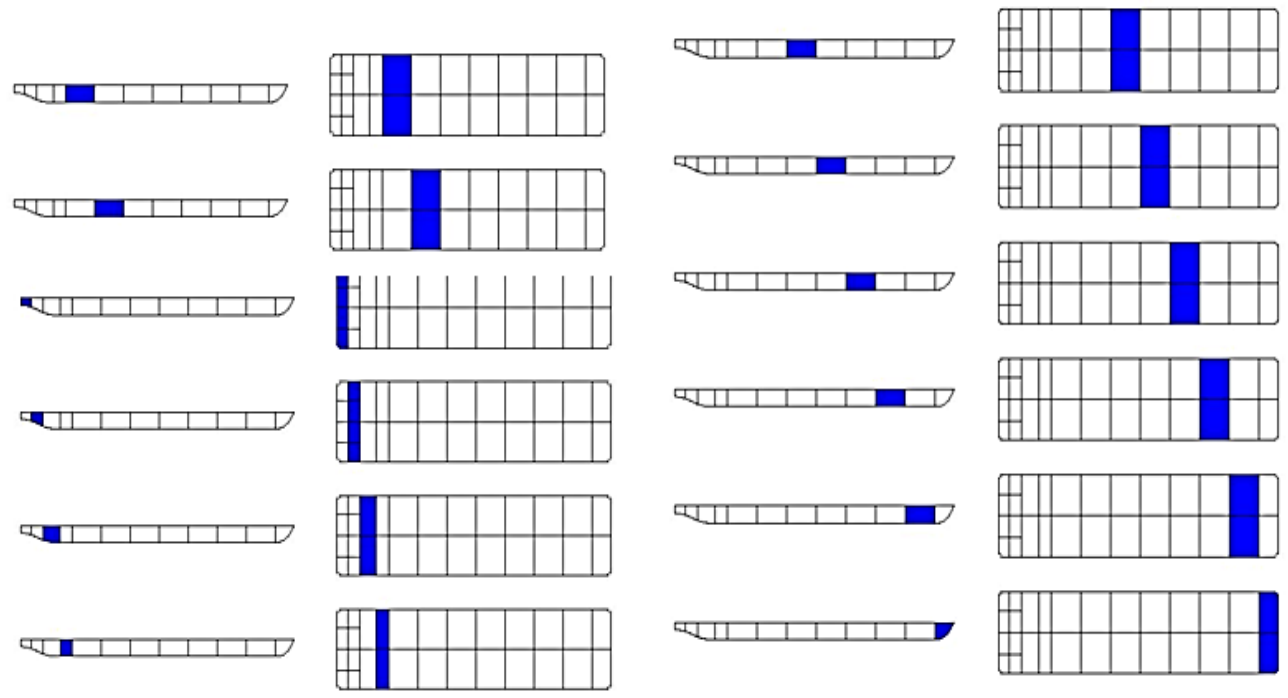

Fig. 1 Simulation of damage zone in 12 different compartments, presented by blue color.

\subsection{Seakeeping analysis}

Potential flow theory is used to build computer programs that estimate the motion response of a floating structure. ANSYS AQWA, which includes a three-dimensional panel code to calculate linear wave forcing and ship motion characteristics in the frequency domain, is a popular tool for computing RAOs [13]. It is critical to accurately estimate ship motion in a complicated maritime environment during the ship design process [14, 15]. Ship motion behavior was divided into six degrees of freedom along the $\mathrm{X}, \mathrm{Y}$, and $\mathrm{Z}$ axes and divided into rotational and translational movements. Heaving is the ship motion parallel to the Z-axis, and when heaving occurs, the ship experiences vertical ups and downs caused by waves. Rolling is the ship's movement around the longitudinal axis or X-axis. When rolling occurs, the right side of the ship moves to the left side of the ship, which repeats alternately [16]. Pitching is defined as rotation along a transverse axis comparable to an axis parallel to the Y-axis. This is a typical maneuver that causes the ship's bow and stern to go up and down.

The seakeeping analysis was conducted by CFD-Based software using the hydrodynamic diffraction method. The modeling of the body hull is the first step in determining the response behavior of the LCT and Livestock Carrier. In general, a panel model is used to define the body surface geometry and mass distribution, followed by a description of the environment. The ship was assumed to operate in Java sea conditions (Kumai Port to Tanjung Perak Port) at wave height $1.25 \mathrm{~m}$ and forward speed of $5.14 \mathrm{~m} / \mathrm{s}$. In the setting of domain geometry, the body shape, movements, forces, and other hydrodynamic parameters were defined using space coordinate systems. The axes system for hydrodynamic analysis were as follows: $\mathrm{X}$-axis is positive towards bow from aft perpendicular (AP-frame 0). From the ship's centerline, the Yaxis is pointed to the portside. The Z-axis is positive upwards from the base line. The model 
has a thickness of $0 \mathrm{~m}$ and is cut across the waterline (draft). The origin of the global coordinate is at LCG in the X-direction, CL in the Y-direction, and KG from the sea surface in the Zdirection. As a result, all hydrodynamic quantities were calculated at the center of gravity. In setting the domain, the basin was set at $5 \mathrm{x}$ LWL in length, $1.5 \mathrm{x}$ LWL in width, and $2 \mathrm{x}$ LWL in water depth. A range of wave frequencies were considered in the calculation of the RAOs at five different waves heading, including following sea $\left(0^{\circ}\right)$, stern quartering sea $\left(45^{\circ}\right)$, beam sea $\left(90^{\circ}\right)$, bow quartering sea $\left(135^{\circ}\right)$, and head sea $\left(180^{\circ}\right)$. The illustration of five different wave heading angles is depicted in Fig. 2.

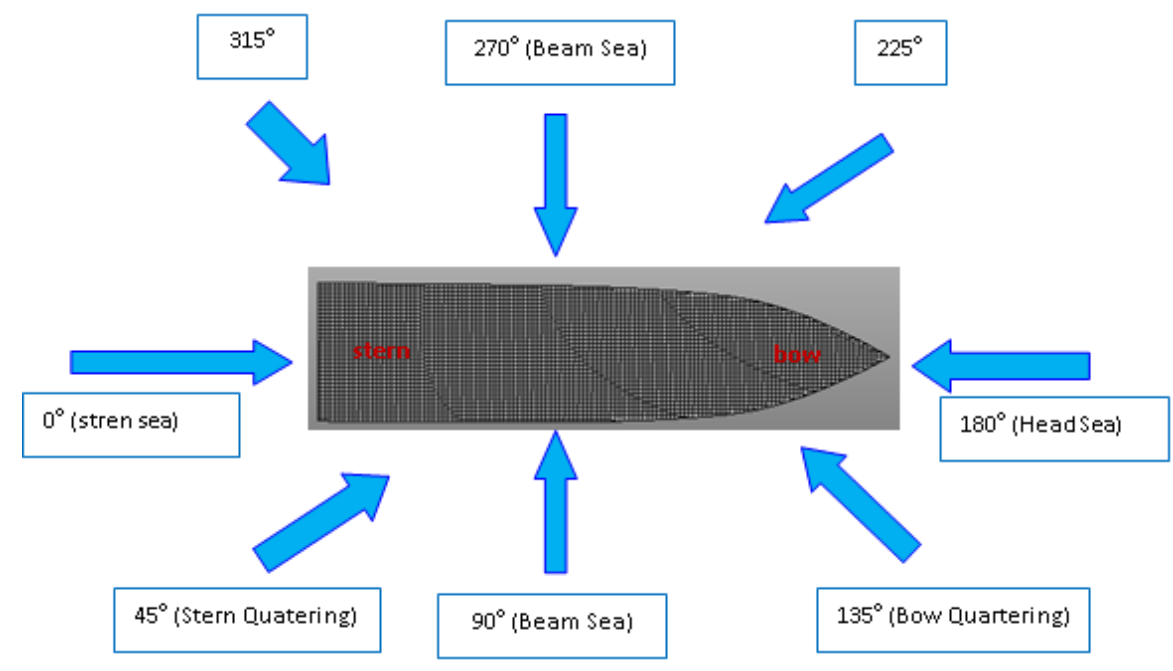

Fig. 2 Heading angle of the ship against wave

\subsection{Resistance calculation}

The fluid force was applied to a body in motion in order to counteract its motion. The component of fluid forces operated parallel to the body's axis of motion [16,17]. $R_{T}$ denotes total resistance, and various components of resistance are defined below. Total resistance is the summary of all drag components work, including friction resistance, wave resistance, appendages resistance, and air resistance. The resistance value affects several factors, including ship velocity, wetted surface area, and hull form. In this case, the ship's resistance is predicted by comparing two different methods: analytical and numerical methods. In the analytical method, in simple terms, the total ship resistance $R_{T}$ can be obtained by adding up all the components of the resistance components working on the ship, which include friction resistance, wave resistance, and air resistance. General formulation of resistance using the Holtrop method can be expressed with the equation as following [18]:

$$
R_{T}=R_{F}\left(1+K_{1}\right)+R_{A P P}+R_{W}+R_{B}+R_{T R}+R_{A}
$$

where $R_{F}$ is the frictional resistance according to the ITTC-1957 friction formula; $1+K_{1}$ is the form factor describing the viscous resistance of the hull form in relation to $R_{F}, R_{A P P}$ is the resistance of appendages, $R_{W}$ is the wave-making and wave-breaking resistance, $R_{B}$ is the additional pressure resistance of bulbous bow near the water surface, $R_{T R}$ is the additional pressure resistance of immersed transom stern and $R_{A}$ is the model-ship correlation resistance.

The second approach was based on the computer-based numerical method. The use of numerical simulation appears as the most straightforward approach with much less time and cost compared to an experimental test [19]. In this case, a numerical test was conducted with speed ranging from 0 knots to 10 knots using the Holtrop-based method for relatively large sized vessels. Moreover, a power calculation was set using $65 \%$ efficiency. The analysis was 
Hartono Yudo, Serliana Yulianti, The Conversion Strategy From Landing Craft Tank Into Livestock Carrier:

done by comparing the resistance and power values between the LCT ship and Livestock Carrier.

\subsection{Economic added value analysis}

Economic added-value analysis was used to determine the feasibility level of LCT vessels after being converted into livestock vessels. The method used in this research was a financial approach that includes calculating $N P V, I R R$, and $P P$ [20].

The net present value $(N P V)$ is the calculation outcome used to determine the current value of a future stream of payments. It takes into consideration the time worth of money and may be used to evaluate similar investment options. The $N P V$ is calculated using a discount rate determined from the cost of capital necessary to make the investment, and any project or investment with a negative $N P V$ should be avoided. $N P V$ formula is expressed as:

$$
N P V=\frac{R_{t}}{(1+i)^{t}}
$$

where $R_{t}$ is the net cash flow at time $t, i$ is the discount rate, and $t$ is the time of the cash flow. When computing $I R R$, the projected cash flows for a project or investment are provided, and the $N P V$ is set to zero. The initial cash investment for the initial period will be equal to the present value of the investment's future cash flows. Once established, the internal rate of return is generally compared to a corporate hurdle rate or cost of capital. The project is a solid investment if the $I R R$ is greater than or equal to the cost of capital. IRR formula is expressed as:

$$
I R R=i_{1}+\frac{N P V_{1}}{N P V_{1}-N P V_{2}}\left(i_{1}-i_{2}\right)
$$

where $i_{1}$ is the lower discount rate chosen, $i_{2}$ is the higher discount rate chosen, and $N P V_{1}$ is equal with $N V P$ at $i_{2}$, and $N P V_{2}$ equals $N V P$ at $i_{1}$. The payback period is the amount of time needed to return the initial cost of an investment. It determines the number of years it would take to repay a project's initial expenditure. As a result, as a capital planning tool, the payback time is used to compare projects and calculate the number of years required to reimburse the initial expenditure. Typically, the project with the shortest number of years is chosen. Analysis of the payback period in the feasibility study also needs to be shown to determine how long the business/project has taken the investment return, as expressed in Eq. 5 [20].

$$
P P=n+(a-b) /(c-b) \times 1 \text { year }
$$

where $n$ is the last year in which the amount of cash flow still cannot cover the initial investment, $a$ is the amount of initial investment, $b$ is the cumulative amount of cash flows in the previous year, and $c$ is the cumulative amount of cash flows in the previous following year.

\section{Result and discussion}

\subsection{Overview of the conversion of LCT ship}

In the phase of ship design, preliminary design and concept design is two important phases. In the first phase, preliminary design is addressed to determine ship's principal characteristic and powering in accordance with national and international maritime rules. The primary ship particular dimensions and hull form characteristics (hull form hydrostatics, powering, weight components, stability, ship motion), are required in the first phase [21].

In this case, the conversion of the LCT ship into a Livestock Carrier is firstly conducted by rearranging the ship layout due to cargo change. The conversion of the LCT ship is done by changing the cargo from 38 trucks ( 988 tons) to livestock of 292 cows dan 228 goats (125 tons). The conversion is accomplished by adding the main deck and bridge deck for livestock, 
water ballast tanks, and freshwater tanks. The illustration of layout rearrangement is depicted in Fig. 3.

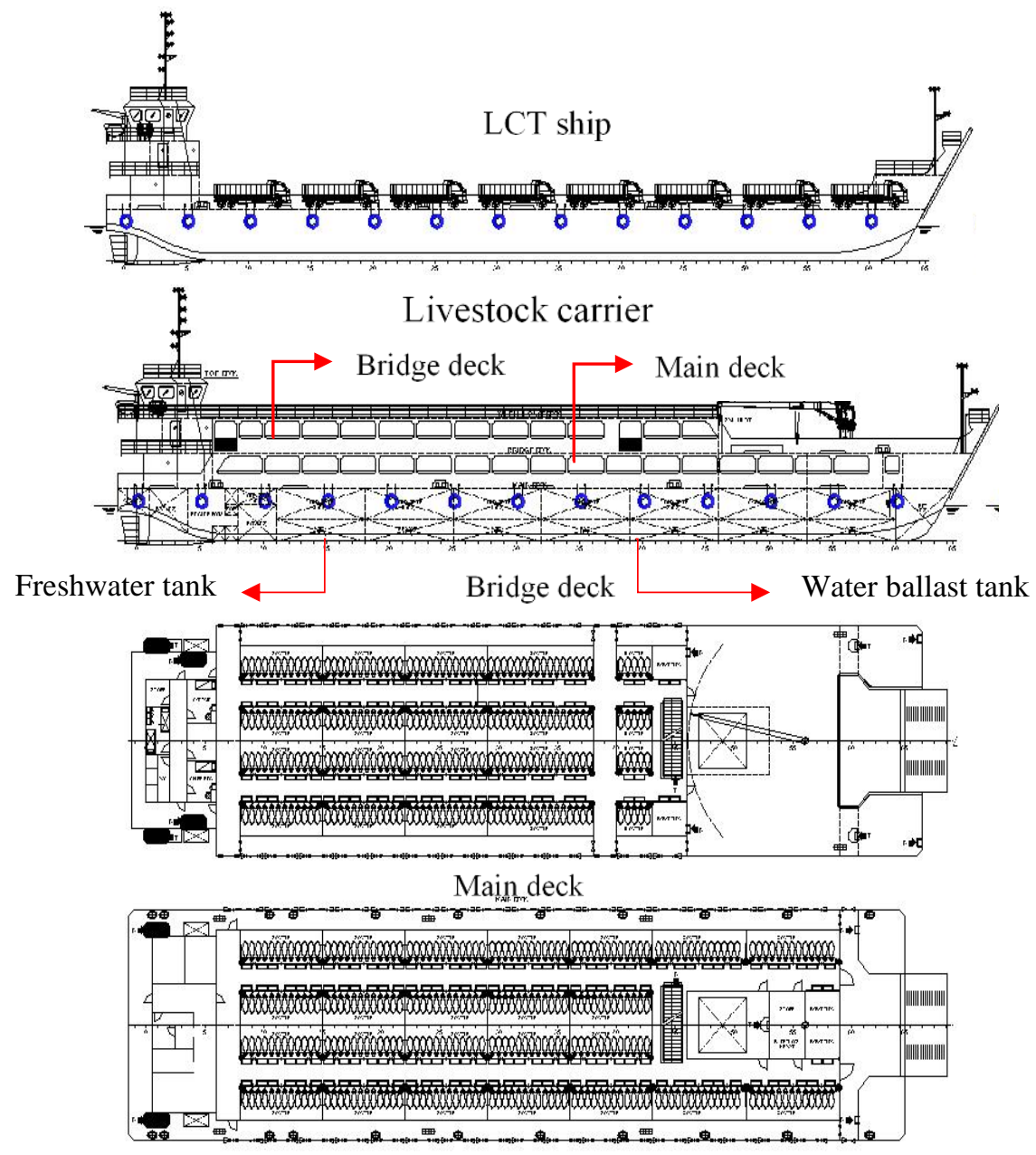

Fig. 3 Layout rearrangement from LCT ship to Livestock Carrier.

As a consequence, there is lightweight addition of cattle pen steel and equipment in total of 325 tons. In deadweight components, there is an increase of water ballast tank to 208 ton and freshwater tank to 145 ton. The comparison of LWT and DWT components are illustrated in Fig. 4 and Fig. 5. Table 2 shows the comparison of the main dimension between the two ships. It can be seen that the size of LOA, B, and $\mathrm{H}$ remains constant, but the draft of Livestock Carrier is decreased to $2.03 \mathrm{~m}$. From data in Table 2, the LWT of the Livestock Carrier is higher due to the weight addition of cattle pen and livestock equipment. In contrast, the DWT of the LCT ship is greater than the Livestock Carrier due to the weight of the truck/ vehicle. Consequently, the displacement of LCT is higher, around 183 tons, compared to Livestock Carrier. The layout change, hydrostatic data, and weight calculation can be used as input data for further technical and economic calculations. 
Hartono Yudo, Serliana Yulianti, The Conversion Strategy From Landing Craft Tank Into Livestock Carrier: Ovin Ranica Pratiwi, Tuswan Tuswan An Overview of Technical Evaluation and Economical Benefit

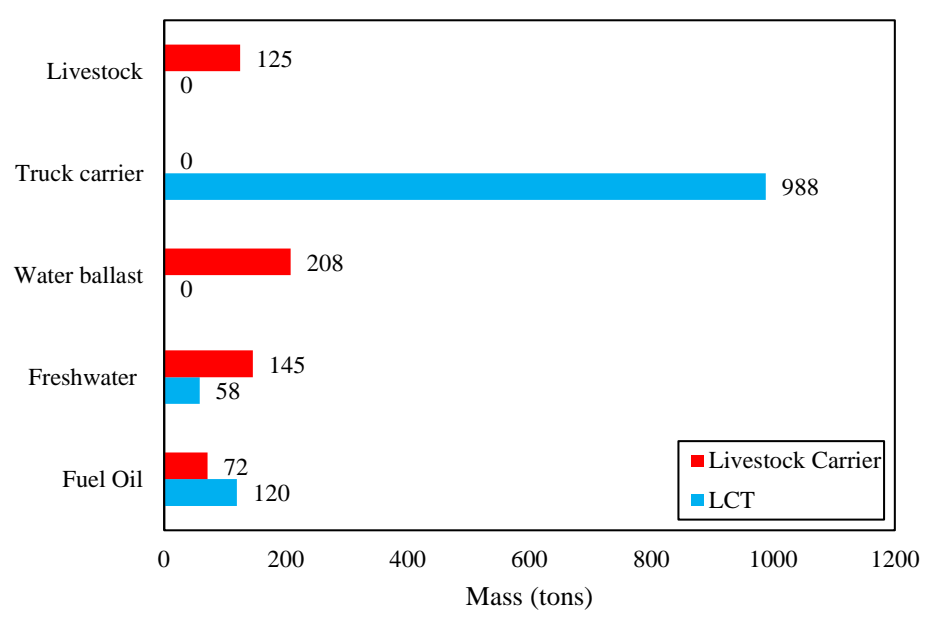

Fig. 4 LCT and Livestock Carrier comparison of deadweight tonnage

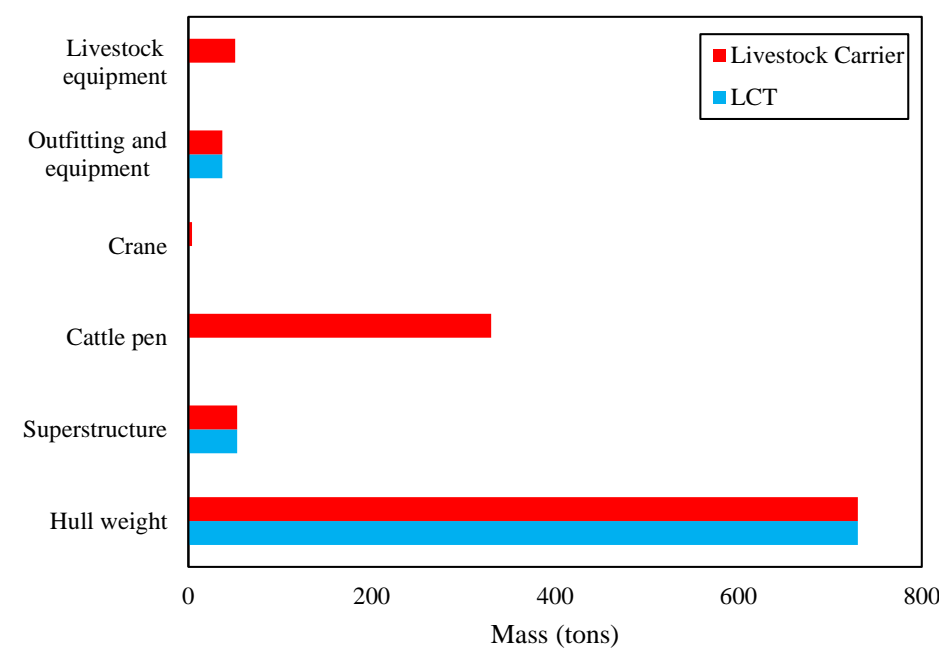

Fig. 5 LCT and Livestock Carrier comparison of lightweight tonnage

Table 2 Main dimension of LCT ship and Livestock Carrier

\begin{tabular}{|l|c|c|}
\hline \multicolumn{1}{|c|}{ Parameters } & LCT & $\begin{array}{c}\text { Livestock } \\
\text { Carrier }\end{array}$ \\
\hline Displacement (tons) & 2254 & 2060 \\
\hline LWT (m) & 848 & 1234 \\
\hline DWT (m) & 1406 & 826 \\
\hline LOA (m) & 70.00 & 70.00 \\
\hline B (m) & 17.00 & 17.00 \\
\hline T (m) & 2.40 & 2.03 \\
\hline H (m) & 3.60 & 3.60 \\
\hline Vs (knots) & 10 & 10 \\
\hline
\end{tabular}

\subsection{Result of intact and damage stability}

Initially, IMO regulation regulated the gross tonnages have to be no less than $500 \mathrm{GT}$ to calculate intact and damage stability [22]. The GT calculation shows that the gross tonnage of LCT is 853 tons, and the gross tonnage of Livestock Carrier is 1553 tons. It can be concluded that the gross tonnage of two ships fulfill the minimum standard. In this case, the result of intact stability analysis of the two ship types using the IMO standard was evaluated. The parameter of each load case between LCT and Livestock Carrier are depicted in Table 3. 
The Conversion Strategy From Landing Craft Tank Into Livestock Carrier:

Hartono Yudo, Serliana Yulianti An Overview of Technical Evaluation and Economical Benefit

Ovin Ranica Pratiwi, Tuswan Tuswan

Table 3 The load case difference between Landing Craft Tank and Livestock-Carrier ship stability items

\begin{tabular}{|l|c|c|c|c|c|c|}
\hline \multirow{2}{*}{ Parameters } & \multicolumn{3}{|c|}{ Landing Craft Tank } & \multicolumn{3}{c|}{ Livestock Carrier } \\
\cline { 2 - 7 } & $\begin{array}{c}\text { Load } \\
\text { case I }\end{array}$ & $\begin{array}{c}\text { Load } \\
\text { case II }\end{array}$ & $\begin{array}{c}\text { Load } \\
\text { case III }\end{array}$ & $\begin{array}{c}\text { Load } \\
\text { case I }\end{array}$ & $\begin{array}{c}\text { Load } \\
\text { case II }\end{array}$ & $\begin{array}{c}\text { Load } \\
\text { case III }\end{array}$ \\
\hline Displacement (tons) & 2254 & 2046 & 1880 & 2060 & 1710 & 1430 \\
\hline DWT (tons) & 1406 & 1198 & 1032 & 826 & 476 & 196 \\
\hline LWT (tons) & 848 & 848 & 848 & 1234 & 1234 & 1234 \\
\hline LCG (m) & 31.9 & 31.7 & 31.6 & 32.7 & 31.8 & 30.9 \\
\hline KG (m) & 2.8 & 3.2 & 3.4 & 2.7 & 3.4 & 3.9 \\
\hline
\end{tabular}

Table 4 Results of intact stability

\begin{tabular}{|c|c|c|c|c|c|c|c|c|}
\hline \multirow[b]{2}{*}{ IMO Criteria } & \multirow[b]{2}{*}{ Unit } & \multicolumn{3}{|c|}{ LCT Model } & \multicolumn{3}{|c|}{ Livestock Model } & \multirow[b]{2}{*}{ Status } \\
\hline & & $\begin{array}{l}\text { Load } \\
\text { case I }\end{array}$ & $\begin{array}{c}\text { Load } \\
\text { case II }\end{array}$ & $\begin{array}{c}\text { Load } \\
\text { case } \\
\text { III }\end{array}$ & $\begin{array}{c}\text { Load } \\
\text { case } \\
\text { I }\end{array}$ & $\begin{array}{c}\text { Load } \\
\text { case } \\
\text { II }\end{array}$ & $\begin{array}{c}\text { Load } \\
\text { case } \\
\text { III }\end{array}$ & \\
\hline Area 0 to 30 & m.deg & 69.03 & 71.17 & 74.28 & 74.63 & 78.4 & 83.2 & Pass \\
\hline Area 0 to 40 & m.deg & 101.68 & 103.76 & 107.78 & 110.1 & 113.4 & 117.97 & Pass \\
\hline Area 30 to 40 & m.deg & 32.65 & 32.6 & 33.5 & 35.46 & 34.97 & 34.74 & Pass \\
\hline $\begin{array}{l}\text { Max GZ at } 30 \text { or } \\
\text { greater }\end{array}$ & $\mathrm{m}$ & 3.4 & 3.43 & 3.53 & 3.68 & 3.68 & 3.69 & Pass \\
\hline Angle of max GZ & deg & 26.4 & 25.5 & 25.5 & 26.4 & 26.4 & 25.5 & Pass \\
\hline Initial GM & $\mathrm{m}$ & 10.4 & 11.1 & 11.8 & 11.33 & 12.76 & 14.87 & Pass \\
\hline
\end{tabular}

In the result of intact stability, it can be found from Table 4 that the result of LCT ships with three different load cases fulfills the six stability criteria given by IMO. It can be compared that the stability of Livestock Carrier has a higher value than stability value of LCT with the same load case. Moreover, it can be seen that the righting arm (GZ) and the angle of max GZ of the Livestock Carrier are higher compared to the LCT ship with the same load case. The maximum righting arm result is proportional to the largest static heeling moment required to bring the ship back to its upright position. Furthermore, the higher the righting arm, the better the ship at returning to initial position.

After conducting intact stability analysis, damage stability analysis is needed to measure the ship's ability on damage conditions. The ship may sink due to flooding of the compartments when buoyancy cannot return the vessel back to its initial position. In this case, the analysis was performed using Maxsurf Stability with simulating damage zone in the 12 compartments, as shown in Fig.1. The permeability value for each compartment is shown in Table 5. Permeability of a space is the proportion of the immersed volume of that space that water can occupy.

The damage stability analysis was performed based on the criteria of IMO MSC 261 (82). Ships should be as efficiently subdivided as possible, having regard to the nature of the intended. The degree of the subdivision should vary with the subdivision length of the ship and with the service, in such manner that the highest degree of subdivision corresponds with the ships of greatest subdivision length. The results of the damage stability analysis are shown in Table 6. The damage stability result qualifies the standard criteria for predetermined LCT and Livestock Carrier. It can be found from the result that the $A$ index value of LCT and Livestock 
Hartono Yudo, Serliana Yulianti, The Conversion Strategy From Landing Craft Tank Into Livestock Carrier: Ovin Ranica Pratiwi, Tuswan Tuswan

An Overview of Technical Evaluation and Economical Benefit

Carrier is 0.879 , and the $R$ index value is 0.576 . The results are all declared acceptable because of $A \geq R$.

Table 5 Permeability value for each compartment [12].

\begin{tabular}{|c|l|c|}
\hline No & \multicolumn{1}{|c|}{ Spaces } & Permeability \\
\hline 1 & Appropiated to stores & 0.6 \\
\hline 2 & Occupied by accomodation & 0.95 \\
\hline 3 & Occupied by machinery & 0.85 \\
\hline 4 & Void spaces & 0.95 \\
\hline 5 & Intended for liquids & 0 or 0.95 \\
\hline
\end{tabular}

Table 6 Results of damage stability

\begin{tabular}{|l|c|c|c|c|c|}
\hline \multicolumn{1}{|c|}{ Model } & $\begin{array}{c}A \\
\text { Factor }\end{array}$ & $\begin{array}{c}R \\
\text { Factor }\end{array}$ & $\begin{array}{c}\text { Index } \\
A\end{array}$ & $\begin{array}{c}\text { Index } \\
R\end{array}$ & Status \\
\hline LCT & 0.977 & 0.5768 & 0.879 & 0.576 & Pass \\
\hline Livestock Carrier & 0.977 & 0.5768 & 0.879 & 0.576 & Pass \\
\hline
\end{tabular}

\subsection{Result of intact and damage stability}

This section conducts seakeeping analysis by comparing the RAO curve of heaving, rolling, and pitching between two ship types at five different wave headings. The analysis is achieved with speed of 10 knots and wave height of 1.25, representing the operation condition of the route from Kumai Port to Tanjung Priok Port, as seen in BMKG data [23]. Analysis of ship motion was done using Ansys Aqwa software using the hydrodynamic diffraction method. Ships moving at sea level are almost always in oscillatory motion. There are three types of movements of purely oscillatory motions, namely heave, roll, and pitch, which causes the ship to experience a restoring force to return the equilibrium position. The ship's motion response to regular waves is depicted in the RAO value, as shown in Fig. 6-8.

The comparison between the RAO heaving values of LCT and Livestock Carrier is shown in Fig. 6. The curve shows the peak of the RAO value curve for the LCT, which is at encounter frequency of $0.427 \mathrm{rad} / \mathrm{s}$ with an RAO value of 1.01 in the following sea condition. Moreover, the peak of heave RAO of LCT ships is at encounter frequency of $0.427 \mathrm{rad} / \mathrm{s}$ with an RAO value of $1.01 \mathrm{~m} / \mathrm{m}$ on following sea conditions. The RAO heaving value of the Livestock Carrier ship is slightly more significant than the RAO heaving value of the LCT. It can be seen that the seakeeping performance due to the heaving motion of the Livestock Carrier has similar behavior. From the results in Fig. 8, heave motion caused by the following sea undergoes a superposition due to more than two peaks of wave frequency, causing the ship to move unevenly.

The comparison between the RAO values of the ship pitching is shown in Fig. 7. It can be analyzed that the pitching motion between the two ships is quite similar. It is caused by similar hull characteristics of the two ship types. The waves from the head sea and bow quartering sea experience higher pitch motion than other wave headings. From the result due to bow quartering sea, the peak of the RAO value of the LCT is at encounter frequency of $1.46 \mathrm{rad} / \mathrm{s}$ with an RAO value of $2.73 \mathrm{deg} / \mathrm{m}$. At the same time, the peak of the pitch RAO of Livestock Carrier is at encounter frequency of $1.4634 \mathrm{rad} / \mathrm{s}$ with an RAO value of $2.70 \mathrm{deg} / \mathrm{m}$. Moreover, a similar phenomenon occurs in the pitch motion in which there is a superposition of more than two peaks of wave frequency in the following sea conditions.

At last, the comparison between the roll RAO values is shown in Fig. 8. From the curve, it can be seen that the highest roll motion is experienced due to beam sea conditions. The peak of roll RAO of LCT is at encounter frequency of $1.57 \mathrm{rad} / \mathrm{s}$ with an RAO value of $14.74 \mathrm{deg} / \mathrm{m}$, 
and the peak of roll RAO of the Livestock Carrier is at encounter frequency of $1.57 \mathrm{rad} / \mathrm{s}$ with an RAO value of $13.07 \mathrm{deg} / \mathrm{m}$. Moreover, the roll RAO due to bow quartering and stern quartering seas has low motion due to the wave headings of bow quartering and stern quartering seas. In contrast, it was revealed that there was no motion found due to wave heading from head sea condition.

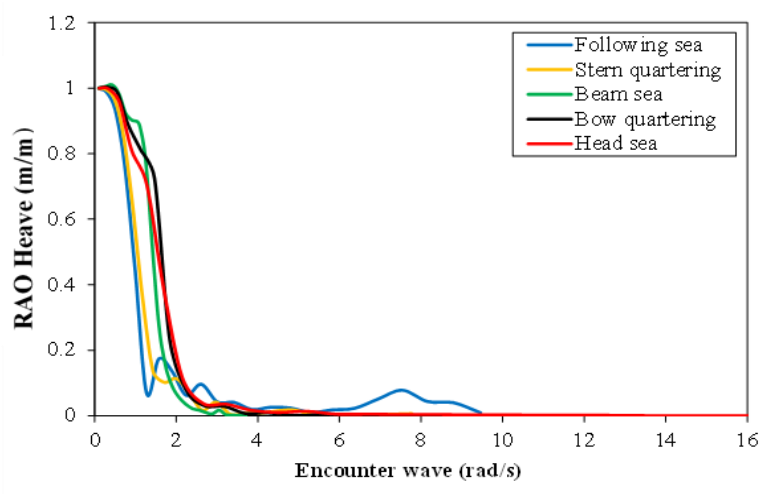

a

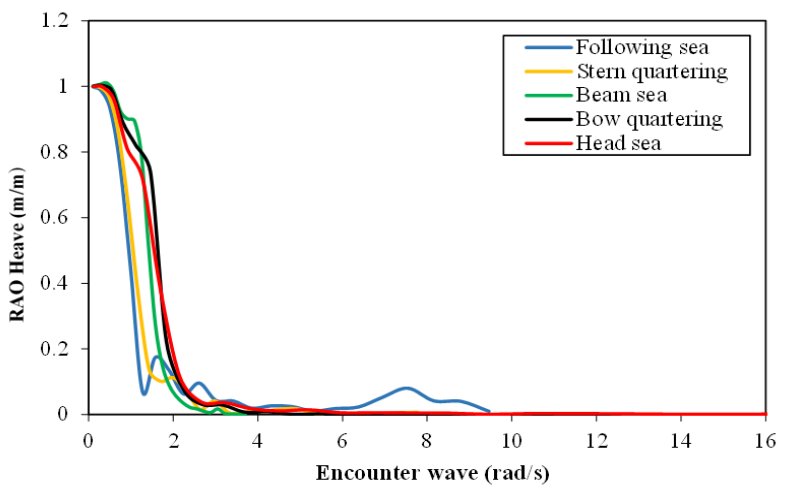

b

Fig. 6 Comparison of heave RAO a) LCT ship b) Livestock Carrier

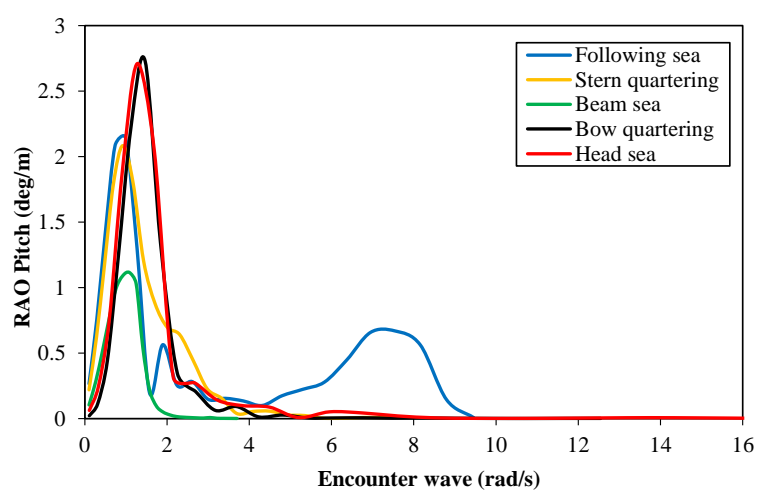

a

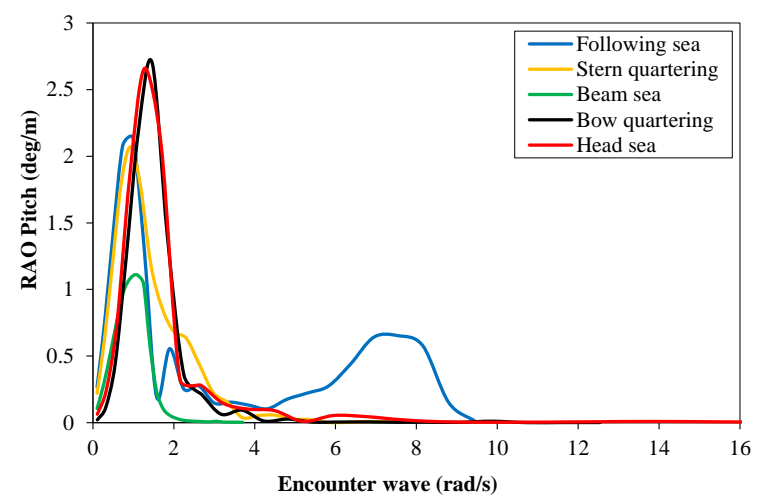

b

Fig. 7 Comparison of pitch RAO a) LCT b) Livestock Carrier

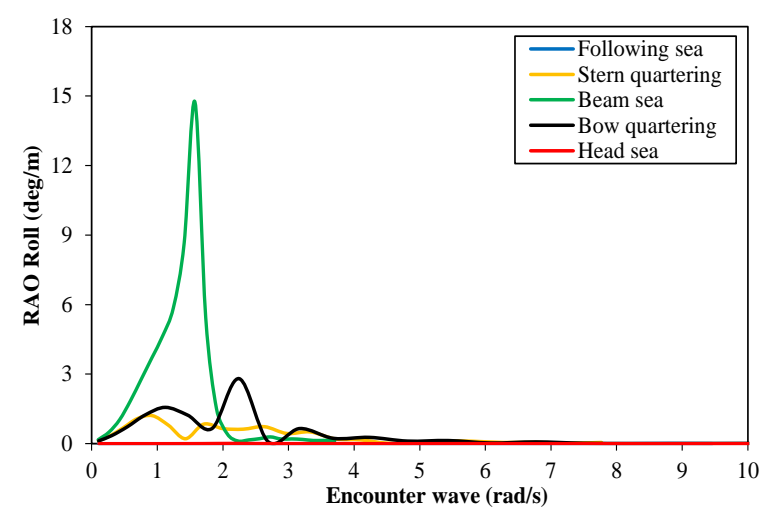

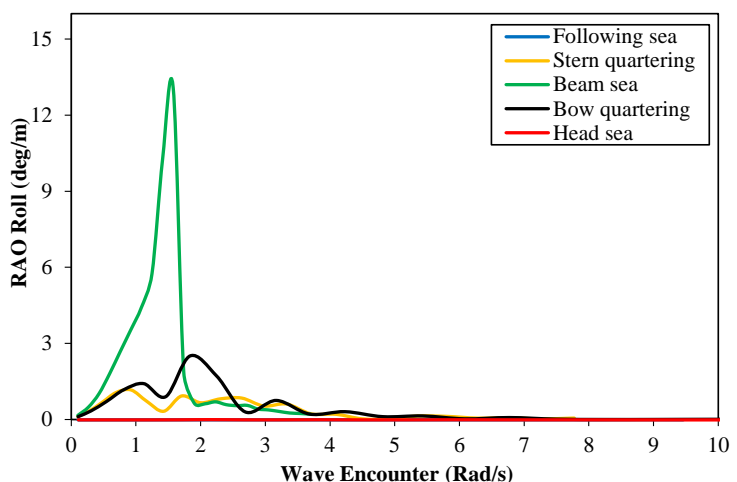

b

Fig. 8 Comparison of roll RAO a) LCT b) Livestock Carrier

In general, the RAO response data can be obtained from the square root of the variances. These values are needed to easily observe the response behavior. RMS values of heave, roll and pitch motions of LCT and Livestock Carrier are presented in Table 6. This study uses the RMS 
Hartono Yudo, Serliana Yulianti, The Conversion Strategy From Landing Craft Tank Into Livestock Carrier:

criteria of NATO STANAG 4154 for LCT vessels [24] and AMSA regulations for Livestock Carrier [25]. It was found that the RMS value of heave, roll, and pitch in all evaluated wave headings of both two ship types fulfill the RMS criteria. It can be seen that the RMS values of LCT and Livestock Carrier have similar values. It is due to the similar hull shapes with different drafts of both ships. Moreover, it was found that the highest heave motion is experienced due to wave heading from the bow quartering sea. Wave heading from beam seas is found to affect the roll motion significantly. In pitch motion, the wave heading from the following sea has the highest response.

Table 7 RMS value between LCT and Livestock Carrier

\begin{tabular}{|c|c|c|c|c|c|c|}
\hline Item & $\begin{array}{c}\text { Wave } \\
\text { Heading }\end{array}$ & $\begin{array}{c}\text { RMS } \\
\text { Criteria }\end{array}$ & LCT & $\begin{array}{c}\text { RMS } \\
\text { Criteria }\end{array}$ & $\begin{array}{l}\text { Livestock } \\
\text { Carrier }\end{array}$ & Unit \\
\hline \multirow{5}{*}{$\begin{array}{l}\text { RMS } \\
\text { Heave } \\
\text { motion }\end{array}$} & $0^{\circ}$ & \multirow{5}{*}{-} & 0.2156 & \multirow{5}{*}{0.67} & 0.2155 & $\mathrm{~m}$ \\
\hline & $45^{\circ}$ & & 0.2307 & & 0.2307 & $\mathrm{~m}$ \\
\hline & $90^{\circ}$ & & 0.2767 & & 0.2768 & $\mathrm{~m}$ \\
\hline & $135^{\circ}$ & & 0.2785 & & 0.2781 & $\mathrm{~m}$ \\
\hline & $180^{\circ}$ & & 0.273 & & 0.2725 & $\mathrm{~m}$ \\
\hline \multirow{5}{*}{$\begin{array}{c}\text { RMS } \\
\text { Roll } \\
\text { motion }\end{array}$} & $0^{\circ}$ & \multirow{5}{*}{4} & 0.0024 & \multirow{5}{*}{8} & 0.0026 & deg \\
\hline & $45^{\circ}$ & & 0.2739 & & 0.2717 & deg \\
\hline & $90^{\circ}$ & & 0.4775 & & 0.469 & deg \\
\hline & $135^{\circ}$ & & 0.3459 & & 0.3494 & deg \\
\hline & $180^{\circ}$ & & 0.0051 & & 0.0057 & deg \\
\hline \multirow{5}{*}{$\begin{array}{l}\text { RMS } \\
\text { Pitch } \\
\text { motion }\end{array}$} & $0^{\circ}$ & \multirow{5}{*}{1.5} & 0.379 & \multirow{5}{*}{2.3} & 0.3786 & deg \\
\hline & $45^{\circ}$ & & 0.3635 & & 0.3627 & deg \\
\hline & $90^{\circ}$ & & 0.0164 & & 0.0164 & deg \\
\hline & $135^{\circ}$ & & 0.0236 & & 0.0236 & deg \\
\hline & $180^{\circ}$ & & 0.0211 & & 0.0211 & deg \\
\hline
\end{tabular}

\subsection{Result of resistance test}

The comparison of the resistance test is discussed in this section. For validation purposes, ship resistance was calculated using both analytical and numerical methods using the Holtrop regression method at a speed of 10 knots (Froude number 0.2). Table 8 shows the comparison result of the validation test of both LCT and Livestock Carrier. It can be seen that the validation test shows a good agreement between the two different methods, represented by a small error below $10 \%$. Furthermore, the validity and effectiveness of the numerical hull shape model can be achieved for both ship types.

The resistance and powering test results at speed in the range of 0-10 knots can be seen in Fig. 9. The result given in Fig. 9 shows a decrease in resistance after converting to Livestock Carrier. Analyzed at a speed of 10 knots, the resistance of LCT was $83.8 \mathrm{kN}$, and the resistance of Livestock Carrier was $75.6 \mathrm{kN}$. It can be interpreted that the resistance of Livestock Carrier is slightly lower, about $9.8 \%$ than LCT ship. It is caused by the decrease of the draft of Livestock Carrier from $2.4 \mathrm{~m}$ to $2.03 \mathrm{~m}$ due to ship conversion. As a result, the wetted surface area is slightly lower than the LCT ship. To conduct further analysis, the power needed for both ship types was calculated at a speed in the range of 0-10 knots with $65 \%$ efficiency. It was found that the powering of Livestock Carrier also decreased as the resistance value decreased. The powering value of the LCT ship was $663 \mathrm{~kW}$, and the Livestock Carrier was $598 \mathrm{~kW}$ at a speed 
of 10 knots. It was found that the power of Livestock Carrier was slightly lower, about $9.8 \%$ than LCT ship.

Table 8 Validation of numerical and theoretical methods

\begin{tabular}{|c|c|c|c|c|}
\hline \multirow{2}{*}{ Model } & \multirow{2}{*}{$\begin{array}{c}\text { Froud } \\
\text { Number }\end{array}$} & \multicolumn{3}{|c|}{ Resistance at 10 knots $(\mathrm{kN})$} \\
\hline & & Analytical & Numerical & Error \\
\hline LCT & 0.2 & 78.1 & 83.8 & $6.80 \%$ \\
\hline Livestock Carrier & 0.2 & 72.2 & 75.6 & $4.49 \%$ \\
\hline
\end{tabular}
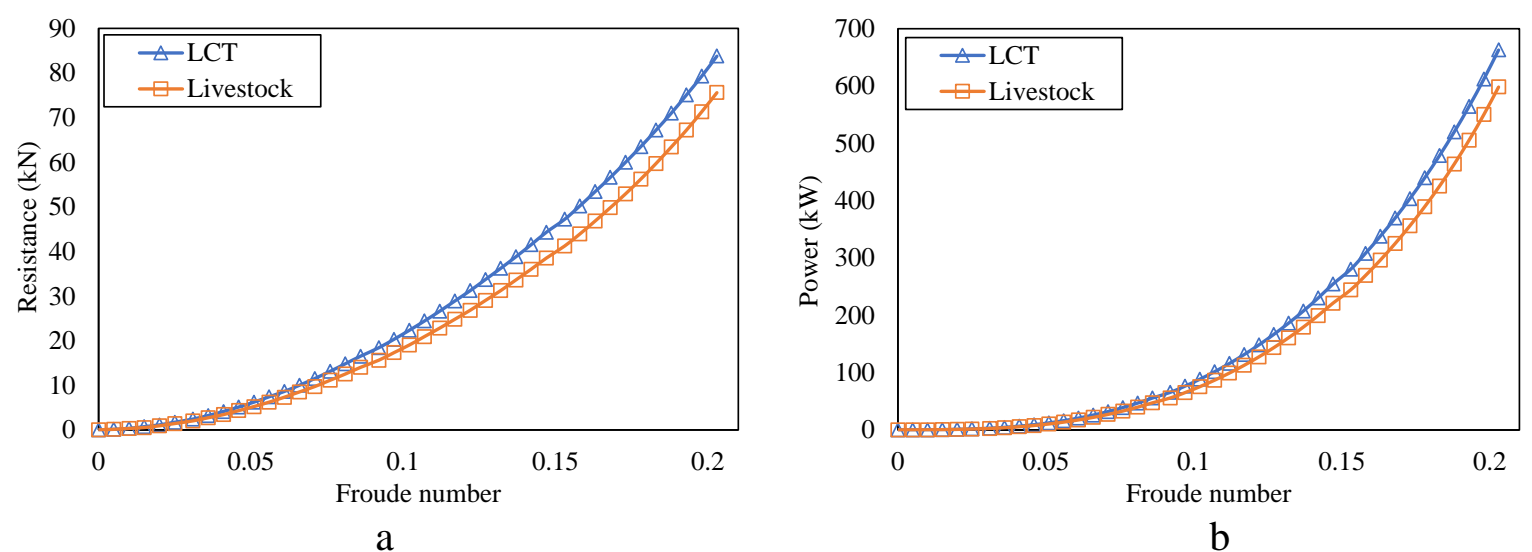

Fig. 9 The result of LCT and Livestock Carrier a) resistance b) powering

\subsection{Economic value-added analysis of ship conversion}

Economic analysis is important to determine the time duration needed to cover the investment costs of the ship conversion. Based on the research results on the Livestock Carrier, a list of LCT operations is presented in Table 9. Ship operating costs are costs incurred in connection with the operation of a vessel on a voyage. The amount of ship operating costs per trip is IDR. 201,418,949.00. It is planned that the boat within a year will work for 48 voyages. Therefore, the costs to be incurred per year are as shown in Table 10. It is assumed that the Livestock Carrier plans to carry livestock with a cattle load capacity of 87.6 tons and a goat load capacity of 21.67 tons. The ideal age for beef cattle is between 12-18 months. The Lambourne formulation and weight calculations of goats was done using the Danish formulation for calculating the weight of livestock. It was calculated that the cow weight is 300 $\mathrm{kg}$, cow load capacity is 292 cows, goat weight is $55 \mathrm{~kg}$, goat load capacity is 394 goats, so the capacity of the cattle that can be transported is 292 cows and 394 goats. The cost of cargo varies by the distance of the ship traveled to the port. The ship is planned to sail from Kumai Port Tanjung Perak Port, Surabaya. It is assumed that the total operation cost per year is IDR $10,536,109,594$, and the total livestock rate per year is IDR $13,510,656,00$.

In this livestock ship investment project, the economic value has a turnover in 15 years. It is necessary to calculate the value of the $I R R$ with 48 trips per year. Prior to calculating the $I R R$, the total discount rate $(d R)$ must be analyzed. The $N P V$ value of $15 \%$ is used because it produces positive results to execute the project. During 15 years of the estimated project life, the present cost value is obtained between the discount rate $\mathrm{dR}$ values of $15 \%$ and $40 \%$. Due to this reason, the Internal Rate of Return (IRR) value is only calculated between the $d R 15 \%$ and $d R 40 \%$. Calculation of the Internal Rate of Return $(I R R)$ of $18.92 \%$ is accepted if the IRR is greater than the discount rate $(d R)$.

The payback period is the length of time it takes to return an investment. Suppose the proceeds each year from a project are the same for the life of the project. In that case, the total investment cost of IDR 7,905,980,500 produces an IRR value of $18.92 \%$. The calculated 
Hartono Yudo, Serliana Yulianti, The Conversion Strategy From Landing Craft Tank Into Livestock Carrier:

turnover and estimate of the ship's durability is 15 years. The payback period or capital costs are covered for 2.25 years.

Table 9 List of operational ship cost

\begin{tabular}{|c|c|c|c|}
\hline Operational items & \multicolumn{2}{|c|}{ Usage cost } & $\begin{array}{l}\text { The number of costs } \\
\text { (per voyage) }\end{array}$ \\
\hline Fuel Oil & IDR 7,500 & litre & IDR $148,061,184$ \\
\hline Lubricating Oil & IDR 26,000 & litre & IDR 19,506,072 \\
\hline Freshwater & IDR 50 & litre & IDR 5,585,286 \\
\hline Salaries and crew allowances & IDR 235,000 & day/person & IDR 13,696,094 \\
\hline Animal Feed & IDR 7,500 & day/tail & IDR $14,570,313$ \\
\hline Total & \multicolumn{3}{|r|}{ IDR $201,418,950$} \\
\hline Total trip for one year & & & IDR $9,668,109,594$ \\
\hline
\end{tabular}

Table 10 List of ship costs per year

\begin{tabular}{|l|l|}
\hline \multicolumn{1}{|c|}{ Outlay } & The amount of cost (per year) \\
\hline Annual trip fee & IDR $9,668,109,594$ \\
\hline Port fee & IDR $48,000,000$ \\
\hline Maintenance fee & IDR $520,000,000$ \\
\hline Assurance & IDR $300,000,000$ \\
\hline Total Outlay & IDR $10,536,109,594$ \\
\hline
\end{tabular}

Table 11 Calculation of the Present Value of Cost $(P V C)$ at several discounts rate values $(d R)$

\begin{tabular}{|l|l|l|l|}
\hline \multicolumn{1}{|c|}{ Operational items } & \multicolumn{2}{c|}{ Usage cost } & \multicolumn{1}{c|}{$\begin{array}{c}\text { The number of costs } \\
\text { (per voyage) }\end{array}$} \\
\hline Fuel Oil & IDR 7,500 & litre & IDR 148,061,184 \\
\hline Lubricating Oil & IDR 26,000 & litre & IDR 19,506,072 \\
\hline Freshwater & IDR 50 & litre & IDR 5,585,286 \\
\hline $\begin{array}{l}\text { Salaries and } \\
\text { allowances for crew }\end{array}$ & IDR 235,000 & day/person & IDR 13,696,094 \\
\hline Animal Feed & IDR 7,500 & day/tail & IDR 14,570,313 \\
\hline Total & \multicolumn{3}{|r}{ IDR 201,418,950 } \\
\hline Total trip for one year & \multicolumn{3}{r}{ IDR 9,668,109,594 } \\
\hline
\end{tabular}

\section{Conclusion}

Some technical and economic assessments due to the conversion of LCT into Livestock Carrier was performed. The general arrangement layout was firstly changed due to the difference in cargo types. The deadweight and lightweight tonnages were then calculated to compare the weight due to conversion purposes. Several results of the technical assessment were obtained. The stability of both intact and damage scenarios were analyzed numerically, and results were found to qualify with the IMO standard in all evaluated shipping operation scenarios. The ship motion analysis shows that seakeeping performance at the shipping conditions from Kumai Port to Tanjung Priok Port represented by RAO of heave, pitch, and roll motion have similar characteristics. The comparative result from five different wave headings shows that pitch motion is significantly influenced by bow quartering and head sea. The roll motion is influenced substantially by beam sea. As the result of the resistance and 
powering test, the Livestock Carrier is more ideal when sailing on the sea with less resistance, and the engine is predicted to be more optimal with less power required.

Moreover, the results of the economic calculation due to the conversion of cargo purposes are decent and comply with the investment project criteria. It was found that the Present Net Value (NPV) value was $15 \%$ and the Internal Rate of Return (IRR) was $18.92 \%$. On the other hand, the Payback Period $(P P)$ calculation value requires a cost of capital of 2.25 years to return the conversion project cost.

\section{Acknowledgments}

The work is supported by the Laboratory of Computer-Aided Design at the Department of Naval Architecture, Universitas Diponegoro, which provides research tools and facilities. The authors gratefully acknowledge the support.

\section{REFERENCES}

[1] Misbah, M.N.; Setyawan, D.; Dananjaya, W.M. (2018). Construction strength analysis of landing craft tank conversion to passenger ship using finite element method. IOP Conference Series: Journal of Physics: Conference Series, 974, 012054. https://doi.org/10.1088/1742-6596/974/1/012054

[2] Zakki, A.F.; Windyandari, A.; Suharto; Ramadhan, A. (2019). Comparative Study on Catamaran and Monohull for The Hull Form Design of Livestock Carrier. Journal of Engineering Science and Technology, 14(4), 2074-2089.

[3] Andric, J.; Piric, K.; Prebeg, P.; Andrisic, J.; Dmitrasinovic, A. (2018). Structural design and analysis of a large 'open type' Livestock Carrier. Ships and Offshore Structures, 1-15. https://doi.org/10.1080/17445302.2018.1429159

[4] Bahatmaka, A.; and Kim, D.J. (2019). Numerical approach for the traditional fishing vessel analysis of resistance by CFD. Journal of Engineering Science and Technology, 14(1), 207-217.

[5] Julianto, R.I.; Prabowo, A.R.; Muhayat, N.; Putranto, T.; Adiputra, R. Investigation of hull design to quantify resistance criteria using Holtrop's regression based method and Savitsky's mathematical model: a study case of fishing vessels. Journal of Engineering Science and Technology, 16(2), 1426-1443.

[6] Chrismianto, D.; Tuswan; Manik, P. (2018). Analysis of resistance and effective wake friction due to addition of stern tunnels on passenger ship using CFD. IOP Conference Series Earth and Environmental Science, 135(1), 012008. https://doi.org/10.1088/1755-1315/135/1/012008

[7] Jurišić, P.; Parunov, J. (2021). Structural aspect during conversion from general cargo ships to cement carriers. Brodogradnja, 72(2), 37-55. https://doi.org/10.21278/brod72203

[8] Manderbacka, T.; Themelis, N.; Bačkalov, I.; Boulougouris, E.; Eliopoulou, E.; Hashimoto, H.; Konovessis, D.; Leguen, J.F.; González, M.M.; Rodríguez, C.A.; Rosén, A.; Ruponen, P.; Shigunov, V.; Schreuder, M.; Terada, D. (2019). An overview of the current research on stability of ships and ocean vehicles: The STAB2018 perspective. Journal of Ocean Engineering, 186, 106090. https://doi.org/10.1016/j.oceaneng.2019.05.072

[9] Im, N. K.; Choe, H. (2021). A quantitative methodology for evaluating the ship stability using the index for marine ship intact stability assessment model. International Journal of Naval Architecture and Ocean Engineering. 13, 246-259. https://doi.org/10.1016/j.ijnaoe.2021.01.005

[10] International Maritime Organization. (2008). Code on intact stability for all types of covered by IMO instruments resolution. MSC.267(85).

[11] International Maritime Organization. (2006). Resolution MSC.216(82).

[12] SOLAS. (2014). Consolidated edition, International Maritime Organization. London.

[13] Nordforsk. (1987). Assessment of Ship Performance in a Seaway: The Nordic Co-operative Project: Seakeeping Performance of Ships, Nordforsk.

[14] Prabowo, A.R.; Tuswan, T.; Ridwan R. (2021). Advanced development of sensors' roles in maritimebased industry and research: from field monitoring to high-risk phenomenon measurement. Applied Sciences, 11(1), 3954. https://doi.org/10.3390/app11093954

[15] Nimma, R.B.; Arundeepan, V.; Shashikala, A.P. (2018). Ship motion in viscous flow under irregular waves. International Journal of Scientific and Engineering Research, 9(4), 8-13.

[16] Poundra, G.A.P.; Utama, I.K.A.P.; Hardianto, D.; Suwasono. (2017). Optimizing trimaran yacht hull configuration based on resistance and seakeeping criteria. Procedia Engineering, 194, 112-119. https://doi.org/10.1016/j.proeng.2017.08.124 
Hartono Yudo, Serliana Yulianti, The Conversion Strategy From Landing Craft Tank Into Livestock Carrier:

[17] Tupper, E.C. (2013). Introduction to Naval Architecture, Fifth Edition. Elsevier Ltd. https://doi.org/10.1016/B978-0-08-098237-3.00001-1

[18] Holtrop, J. (1988). A statistical resistance prediction method with a speed dependent factor. Proceedings of the Scientific and Methodological Seminar on Ship Hydrodynamics (SMSSH). Varna, Bulgaria.

[19] Tuswan; Zubaydi, A.; Piscesa, B.; and Ismail, A. (2020). Dynamic characteristic of partially debonded sandwich of ferry ro-ro's car deck: a numerical modelling. Open Engineering, 10, 424-433. https://doi.org/10.1515/eng-2020-0051

[20] Abdillah, H.N.; Artana, K.B.; Ariana, I.M.; and Masroeri, A.A. (2018). Technical and Economic Analysis of LCT (Landing Craft Tank) Vessel Conversion into Non Conventional LNG (Liquid Natural Gas) Carriers. Proceeding of Marine Safety and Maritime Installation (MSMI 2018), 322-329.

[21] Prabu, C.S.K.; Vishwanath, N.; Prakash, S.O. (2020). Study on the lightship characteristic of merchant ships. Brodogradnja, 71(3), 37-70. https://doi.org/10.21278/brod71304

[22] Tonnage. (1969). International convention on tonnage measurement of ships.

[23] BMKG-Ocean Forest System, (2021). Significant Wave Height. Retrieved January 1, 2021, from: https://peta-maritim.bmkg.go.id/ofs/

[24] Standardization agreement (STANAG). (2000). Common Procedures for Seakeeping in the Ship Design Process. North Atlantic Treaty Organization, Military Agency for Standardization

[25] AMSA (2006). Marine Order 43 (Cargo and cargo handling — livestock).

\author{
Submitted: 06.07.2021. Hartono Yudo \\ Associate Professor, Department of Naval Architecture, Universitas \\ Accepted: 30.08.2021. Diponegoro, Semarang, Indonesia (hartono.yudo@yahoo.com) \\ Serliana Yulianti \\ Research scholar, Department of Naval Architecture, Universitas Diponegoro, \\ Semarang, Indonesia \\ Ovin Ranica Pratiwi \\ Research scholar, Department of Naval Architecture, Universitas Diponegoro, \\ Semarang, Indonesia \\ Tuswan Tuswan \\ Associate Professor, Department of Naval Architecture, Universitas \\ Diponegoro, Semarang, Indonesia
}

